\title{
Kajian Eksploratif Kualitas Penyelenggaraan Pendidikan Lembaga Keuangan Berbasis Pemberdayaan Masyarakat: Studi Kasus Credit Union Kridha Rahardja
}

\author{
Stephanus Eri Kusuma ${ }^{1}$ dan Fransisca Desiana Pranatasari ${ }^{2}$ \\ ${ }^{1,2}$ Fakultas Ekonomi, Universitas Sanata Dharma \\ email: ${ }^{1}$ steriks@usd.ac.id, ${ }^{2}$ fr.desiana@usd.ac.id
}

\section{Artikel History: \\ Artikel masuk \\ Artikel revisi \\ Artikel diterima}

Keywords:

credit union, pendidikan, keberlanjutan, tata organisasi, standar

\section{Style APA Referencing Standard dalam mensitasi artikel ini: [Heading sitasi] Satu, N. P., \& Dua, N. P. (Tahun). Judul Artikel.MSDJ : Management Sustainable Development Journal, $v(n)$, Halaman awal - Halaman akhir. [heading Isi sitasi]}

\begin{abstract}
ABSTRAK
Penelitian ini bertujuan untuk melakukan kajian eksploratif terkait kualitas penyelenggaraan aktivitas pendidikan anggota CUKR, mengidentifikasi permasalahan-permasalahan yang menghambat efektivitas penyelengggaraan pendidikan anggota CUKR. Penelitian dilakukan dengan metode kualitatif deskriptif dengan teknik pengumpulan data dengan cara triangulasi yaitu dengan observasi, wawancara dan analisis dokumen. Hasil Penelitian menunjukkan bahwa sebagian besar peserta pelatihan merasakan adanya manfaat positif dari kegiatan pendidikan anggota CUKR sebagai sarana untuk mengubah pola pikir dan berlatih mengelola keuangan rumah tangga. Meskipun demikian, penyelenggaraan pendidikan anggota CUKR masih relatif terkendala dalam hal penyiapan teknis dan pengorganisasian kegiatan, ketersediaan sumber daya fasilitator dengan kapasitas yang memadai, serta materi terstandar yang mampu mengakomodasi kebutuhan anggota. Dalam mengatasi persoalan tersebut, studi merekomendasikan perlunya tata organisasi penyelenggaraan kegiatan yang lebih terstruktur yang didasari pada mekanisme perencanaan, pelaksanaan, dan evaluasi-refleksi.
\end{abstract}

\section{ABSTRACT}

This study aims to carry out exploratory studies related to the quality of the implementation of educational activities for CUKR members, to identify problems that hinder the effectiveness of the educational implementation of CUKR members. The research was conducted using descriptive qualitative methods with data collection techniques by means of triangulation, namely by observation, interviews and document analysis. The results showed that most of the training participants felt that there were positive benefits from the educational activities of CUKR members as a means to change their mindset and practice managing household finances. Nevertheless, the implementation of education for CUKR members is still relatively constrained in terms of technical preparation and activity organization, the availability of facilitator resources with adequate capacity, and standardized materials that are able to accommodate the needs of members. In overcoming this problem, the study recommends the need for a more structured organizational structure for carrying out activities based on planning, implementation, and evaluationreflection mechanisms. 


\section{PENDAHULUAN}

Credit Union (CU) merupakan gerakan koperasi mandiri yang menyediakan layanan keuangan serta berupaya mewujudkan kesejahteraan sosial dan ekonomi bagi anggotanya dan komunitas yang ada di sekitarnya (McKillop\&Wilson, 2014). Peran CU dalam sektor jasa layanan keuangan menjadi semakin penting dari waktu ke waktu (Atkinson, 2014; Kalmi, 2012; Martinez-Campillo \& Fernandez-Santos, 2017; McKillop \& Wilson, 2011). Di tingkat global, pada tahun 2017, terdapat 89,026 CU yang tersebar di 117 negara, melayani lebih dari 260 juta anggota, serta mengelola sekitar US\$ 2,1 triliun aset (WOCCU, 2018). Di Indonesia, CU menjadi salah satu koperasi keuangan yang paling maju dan berkelanjutan, tersebar di berbagai wilayah perdesaan hingga perkotaan, dan dimiliki oleh dan melayani masyarakat berpendapatan menengah ke bawah (Irnawan, 2010; Kusumajati \& Nopirin, 2012; Sumarwan \& Taruk, 2016). Pada tahun 2016, Indonesia memiliki 887 CU yang melayani 2,8 juta anggota dan memiliki aset sebesar Rp27,7 triliun (US\$2,063 miliar) (Inkopdit, 2017).

Pendidikan dan pelatihan merupakan elemen yang esensial dalam praktek berkoperasi (Byrne et al., 2002). Oleh karena itu, pendidikan menjadi salah satu prinsip dasar koperasi, termasuk Credit Union. Bahkan di dalam gerakan Credit Union, terdapat semboyan 'no study, no credit union' yang berarti tanpa ada pendidikan, tidak ada credit union. Credit Union mempromosikan secara aktif pendidikan di bidang ekonomi, sosial, dan demokrasi, prinsip tolong menolong dan kebijaksanaan dalam menggunakan sumber daya, serta sikap bertanggungjawab kepada anggota, staf, serta masyarakat di sekitarnya (Volkova \& Baltaca, 2013). Menurut Volkova \& Baltaca, meskipun pendidikan menjadi pijakan dasar dalam aktivitas koperasi, komitmen terhadap penyelenggaraan pendidikan yang semakin menurun seiring dengan peningkatan jumlah anggota dan skala operasi menjadi salah satu masalah umum yang terjadi di banyak koperasi, termasuk CU.

Salah satu Credit Union yang sedang berkembang di wilayah Yogyakarta dan Jawa Tengah adalah Credit Union Kridha Rahardja (CUKR). ${ }^{1}$ CUKR diresmikan pada tahun 2017 sebagai gabungan dari 3 unit pelayanan Credit Union di bawah payung Credit Union Bererod Gratia. Secara operasional, CUKR sudah beroperasi sebagai tempat pelayanan sejak tahun 2008. CUKR memiliki 3 tempat pelayanan (TP), yaitu TP. Bawen (Semarang, Jawa Tengah),

\footnotetext{
${ }^{1}$ CUKR menyediakan berbagai jenis produk simpanan dan pinjaman, perlindungan simpanan dan pinjaman, bantuan sosial (misalnya untuk kematian), serta pendampingan usaha anggota.

Judul : Kajian Eksploratif Kualitas Penyelenggaraan Pendidikan Lembaga Keuangan Berbasis Pemberdayaan Masyarakat : Studi Kasus Credit Union Kridha Rahardja

MSDJ : Management Sustainable Development Journal. Semua hak cipta dilindungi undang-undang
} 
TP. Wedi (Klaten, Jawa Tengah), dan TP. Yogyakarta (Bantul, DIY). Pada Desember 2018, CUKR melayani 2691 anggota dengan nilai aset 26,8 milliar rupiah.

Terkait dengan aktivitas pendidikan anggota, CUKR menyelenggarakan beberapa jenis pendidikan, yaitu pendidikan dasar, pendidikan literasi keuangan, dan pendidikan kewirausahaan. Data menunjukkan bahwa partisipasi anggota CUKR dalam 3 jenis kegiatan pendidikan anggota yang disediakan oleh CUKR ternyata masih rendah. Berdasarkan Laporan Pengurus dalam Rapat Anggota Tahunan CUKR Tahun Buku 2018, diperoleh informasi bahwa jumlah anggota CUKR yang mengikuti pendidikan dasar, pendidikan literasi/melek keuangan, dan pendidikan ketrampilan, masing-masing adalah 68\%, 22\%, dan 7\%. Selain data tersebut, hal yang juga patut menjadi perhatian adalah tingginya angka kredit lalai CUKR. Hal ini mengindikasikan adanya permasalahan dalam penyelenggaraan pendidikan CUKR yang bisa bersumber dari dua sisi, supply atau demand. Selain itu, hal yang juga patut diperhaitikan adalah data yang menunjukkan bahwa rasio pinjaman lalai terhadap pinjaman beredar anggota mencapai $16,78 \%$ atau dapat dikatakan jauh dari rasio ideal lembaga keuangan, maksimal sebesar 5\%. Capaian pinjaman lalai ini menjadi potret yang menunjukkan bahwa masih cukup banyak anggota yang belum memiliki kesadaran akan tanggung jawabnya untuk mengembalikan pinjamannya atau dengan kata lain pendidikan di CUKR belum bisa disebut berhasil.

Rendahnya partisipasi anggota dan tingginya pinjaman lalai CUKR memunculkan pertanyaan kritis terkait kualitas penyelenggaraan pendidikan anggota CUKR. Dari sisi penyedia jasa pendidikan (supplier), apakah CUKR sudah cukup menyediakan sistem kelembagaan pendidikan yang sesuai dengan konteks lingkungan dan kebutuhan anggota CUKR, baik dari sisi kebijakan, fasilitator (pemateri), materi, informasi dan infrastruktur pendukung pendidikan anggota lainnya? Sementara itu, dari sisi penerima jasa pendidikan (konsumen), apakah anggota memiliki motivasi yang kuat untuk belajar dan menerapkan materi pendidikan, mampu menangkap materi pembelajaran, serta merasakan manfaat dari pendidikan yang diberikan CUKR? Berangkat dari 2 pertanyaan kritis tersebut, penelitian ini berupaya untuk menganalisis penyelenggaraan aktivitas pendidikan CUKR dari perspektif penerima (consumer) maupun penyedia (supplier) pendidikan anggota, mengidentifikasi permasalahan-permasalahan yang menghambat efektivitas penyelengggaraan pendidikan anggota CUKR, serta memberikan rekomendasi strategi yang mampu mendukung optimalnya penyelenggaraan pendidikan CUKR. 


\section{KAJIAN LITERATUR}

\section{Pendidikan Credit Union}

Pendidikan ditempatkan sebagai pilar utama gerakan Credit Union (CU). Melalui pendidikan seseorang dengan pemikiran baru, perilaku dan karakter baru yang dapat membuatnya sadar bahwa kesejahteraan itu diciptakan sendiri. Menurut Wahono et al. (2014), semua program atau kegiatan pendidikan Credit Union memiliki tujuan untuk meningkatkan kapasitas sumber daya manusia para anggota. Pembedaannya terletak pada sasaran pendidikan tersebut. Wahono et al. (2014) membedakan jenis pendidikan anggota CU berdasarkan sasarannya, yaitu: (1) pendidikan motivasional yang bertujuan untuk mengenalkan Credit Union (CU) secara umum kepada masyarakat yang berpotensi menjadi bagian dari gerakan CU; (2) pendidikan dasar yang bertujuan untuk membuat peserta lebih jauh mengenali dan memahami kondisi pribadi dan lingkungan dengan benar, asal-usul CU, prinsip- prinsip dasar, aturan-aturan, jaringan, hak anggota, tanggungjawab anggota serta hak dan kewajiban anggota; (3) pendidikan lanjutan yang bertujuan untuk meningkatkan kesadaran, memperluas pengetahuan dan wawasan, serta membangun keterampilan anggota yang telah tergabung dalam gerakan Credit Union.

Pendidikan anggota merupakan salah satu hal yang mendasar dan penting bagi keberlanjutan sebuah Credit Union (CU). Penyelenggaraan pendidikan diharapkan dapat menjadi sarana untuk mengenal nilai-nilai dasar CU, berkontribusi secara baik di lembaga CU-nya, serta sekaligus mengembangkan kapasitasnya sehingga menjadi lebih berdaya. Selanjutnya, hal tersebut berdampak positif terhadap pengembangan usaha anggota dan perkembangan $\mathrm{CU}$, yang selanjutnya mendorong hubungan mutualis yang saling menguatkan pencapaian antara CU dan anggotanya sehingga menopang keberlanjutan CU (lihat Gambar 2). 


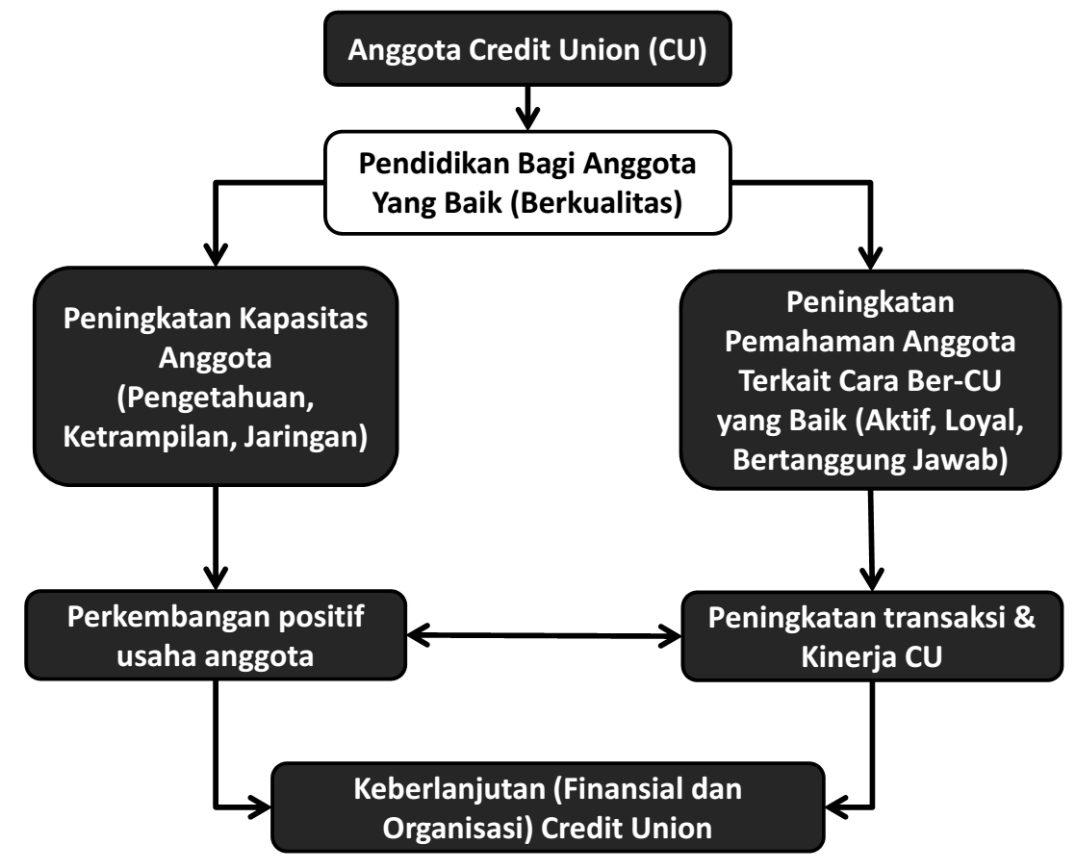

\section{Gambar 2. Hubungan antara Penyelenggaraam Pendidikan Bagi Anggota dan Keberlanjutan CU}

Dalam konteks CUKR yang terindikasi memiliki penyelenggaran yang kurang baik, diperlukan sebuah evaluasi terkait dengan kualitas penyelenggaraan pendidikan anggota di CUKR, baik dari perspektif anggota sebagai penerima aktivitas pendidikan (konsumen) maupun dari perspektif CUKR sebagai penyedia aktivitas pendidikan (supplier). Hal ini dilakukan sebagai sarana untuk mengetahui permasalahan yang terjadi dalam penyelenggaraan pendidikan dan, selanjutnya menjadi sarana untuk membangun desain kelembagaan pendidikan yang dapat meningkatkan efektivitas penyelenggaraan pendidikan bagi anggotanya dan menopang keberlanjutan Credit Union Kridha Rahardja. Kerangka Analisis Penelitian ini dapat digambarkan dalam diagram sebagai berikut (Gambar 3). 


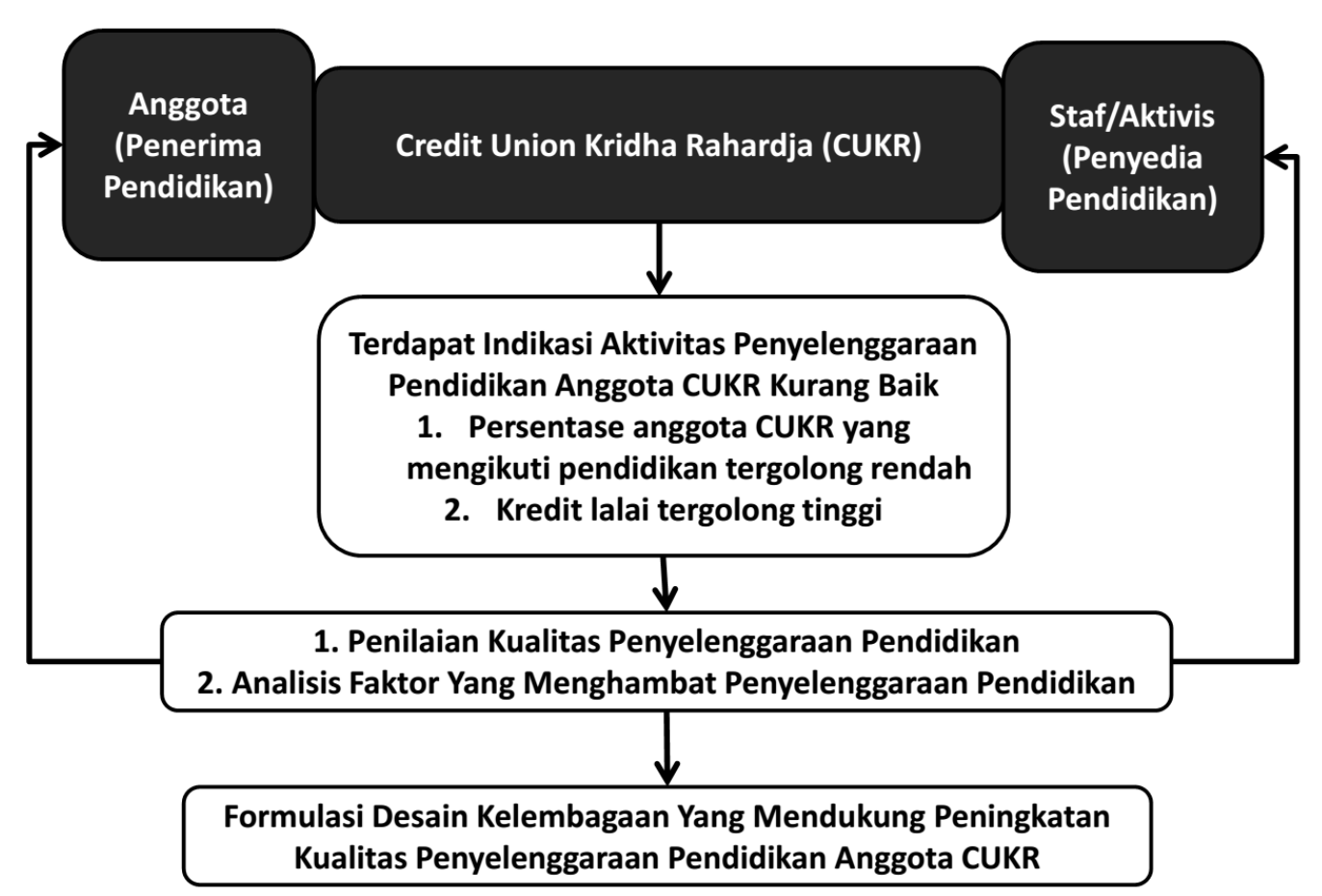

\section{Gambar 3. Penyelenggaraan Pendidikan Bagi Anggota di CUKR dan Alur Penelitian}

\section{Inovasi Pendidikan Credit Union}

Generasi milenial umumnya memiliki kesulitan untuk menjelaskan perbedaan antara bank dan credit union (Moghaddam et al, 2016). Kebanyakan dari mereka hanya memahami credit union sebagai media mereka untuk mengajukan pinjaman/kredit tanpa menjelaskan manfaat lainnya. Hal ini disebabkan karena generasi milenial ini memiliki pengalaman perbankan yang lebih sedikit daripada generasi lainnya, yang kemungkinan besar hanya memperbesar kebingungan mereka dalam pemahaman credit union. Apabila fenomena ini tidak segera dicari solusinya, maka credit union akan mengalami kesulitan dalam proses rekrutmen anggotanya yang berakibat kurang baik bagi masa depan Credit Union. Oleh karena itu, pendekatan dan pendidikan yang tepat merupakan solusi yang akan memberikan kontribusi bagi masa depan Credit Union (Moghaddam et al, 2016).

Credit Union sebaiknya menyesuaikan desain pengembangan pendidikan dengan berusaha memahami perilaku objek pendidikannya yang mulai didominansi oleh usia generasi milenial. Dengan memahami interseksi antara perilaku generasi milenial dengan misi Credit Union, maka masa depan Credit Union akan menjadi preferensi generasi milenial 
(Moghaddam et al, 2016). Generasi milenial memiliki kecenderungan untuk mencari komunitas dengan nilai dan misi yang selaras dengan nilai mereka sendiri, bahkan dapat membela hal yang mereka percaya bahwa itu benar (Moghaddam et al, 2016). Gagasan bahwa Credit Union merupakan unit nirlaba ini cocok untuk generasi milenial umumnya. Dengan menjadikan mereka bagian dari organisasi yang aktif, maka akan memberikan dampak positif bagi Credit Union yang kemudian membentuk pola rekomendasi dua arah melalui word of mouth positif dan rekomendasi kepada keluarga, orang kepercayaan atau teman (Moghaddam et al, 2016).

Hal pertama dan utama untuk membangun ini adalah melalui pendidikan. Pendidikan terkadang dianggap sebagai sektor yang tahan terhadap perubahan, sementara di saat yang sama ia menghadapi krisis produktivitas dan efisiensi (OECD, 2016). Inovasi pendidikan dapat membantu meningkatkan kualitas pendidikan dan juga dapat memperkuat pemahaman nilai sebuah organisasi. Inovasi dalam konteks pendidikan sebaiknya mencari cara terbaik yang dapat diukur dengan mempertimbangkan keterampilan apa yang diperlukan untuk mendorong inovasi lebih luas. Menurut OECD (2016), ukuran inovasi dalam pendidikan melalui variasi pedagogi dan variabel organisasi:

1. Terdapat peningkatan yang besar dalam praktik pedagogik di semua aspek seperti menghubungkan pembelajaran dengan kehidupan nyata, ketrampilan tingkat tinggi, intepretasi dan personalisasi pembelajaran;

2. Pendidik telah berinovasi dalam penggunaan penilaian mereka, aksesibilitas, dan penggunaaan sumber daya dukungan untuk instruksi;

3. Organisasi pendidikan telah berinovasi di bidang pendidikan khusus, penciptaan komunitas pembelajaran profesional untuk guru, evaluasi dan analisis, dan pembangunan hubungan dengan pemangku kepentingan eksternal, seperti orang tua;

4. Secara umum, kinerja pembelajaran dapat dilihat dari hasil belajar peserta didik;

5. Sistem pendidikan yang inovatif umumnya memiliki tingkat pengeluaran yang lebih tinggi daripada yang tidak inovatif sistem tetapi siswa mereka akan lebih puas daripada yang kurang inovatif.

Pendidikan sebaiknya menyesuaikan dengan perilaku dan kebutuhan peserta didik. Inovasi kurikulum pendidikan yang menitikberatkan pada poin pembelajaran melalui Judul : Kajian Eksploratif Kualitas Penyelenggaraan Pendidikan Lembaga Keuangan Berbasis Pemberdayaan Masyarakat : Studi Kasus Credit Union Kridha Rahardja (C) 2021 MSDJ : Management Sustainable Development Journal. Semua hak cipta dilindungi undang-undang 
penciptaan nilai bersama yang secara aktif bersama mitra akan menghasilkan hubungan yang berkelanjutan (OBE dan Templeman, 2013). Dengan desain inovasi kurikulum yang tepat pembelajaran dapat mendorong terwujudnya pemahaman mengenai analisis sosial dan pentingnya kebutuhan ekonomi untuk regenerasi ekonomi. Dalam hal ini, inovasi dalam pendidikan menjadi bagian dari inovasi di bidang ekonomi dan masyarakat (OECD, 2016).

Beberapa literatur mendefinisikan bahwa inovasi sebagai bentuk implementasi sehingga tidak hanya dari ide-ide baru, pengetahuan dan praktik tetapi juga dari peningkatan gagasan, pengetahuan, dan praktik (OECD, 2016). Yang perlu disadari bahwa konsep inovasi berbeda dengan reformasi atau perubahan OECD (2016) mendefinisikan inovasi sebagai "implementasi yang baru atau produk atau proses yang ditingkatkan secara signifikan (baik atau layanan), metode pemasaran baru, atau baru metode organisasi dalam praktik bisnis, organisasi di tempat kerja, atau hubungan eksternal.

Penggunaan pembelajaran yang kreatif berbasis teknologi sebaiknya digunakan untuk memperkuat identitas merek suatu organisasi dan menjadi salah satu pendekatan berkelanjutan untuk terus berbagi konten kurikulum inovatif di seluruh sektor (OBE dan Templeman, 2013). Kekuatan teknologi digital pada ekonomi dan masyarakat juga mencakup tentang pola kerja, komunikasi, keterlibatan kegiatan sosial sehingga dengan adanya inovasi teknologi ini akan mendorong menuju kehidupan yang berbeda (OECD, 2016). Kapasitas inovatif dari teknologi sangat dikondisikan oleh tingkat keterampilan digital pendidik dan peserta didik. Hal ini membutuhkan adanya korelasi yang sangat kuat antara pendidikan dan keterampilan serta penggunaan dan penggunaan teknologi digital di berbagai bidang kehidupan. Peran pendidikan dan keterampilan dalam mempromosikan inovasi pendidikan berbasis teknologi ini sangat penting. Dengan demikian yang perlu dikembangkan oleh sebuah proses pembelajaran adalah digitalisasi, praktek digital dan ketrampilan digital baik dari pendidik maupun peserta didik. Menurut OECD (2016), kunci utama inovasi pendidikan yaitu:

1. Model yang didukung teknologi seperti model berbasis game, laboratorium online percobaan dan penilaian formatif real-time dapat meningkatkan pemahaman konseptual serta meningkatkan kreativitas, imajinasi dan keterampilan memecahkan masalah.

2. Jangkauan luas memungkinkan pembelajaran kolaboratif 
3. Pembelajaran sesuai kebutuhan dan keterampilan yang komprehensif.

Inovasi pendidikan sebaiknya menciptakan lingkungan belajar inovatif yang dilengkapi dengan kolaborasi, eksperimen, dan tanya jawab latihan sendiri (Kovacs, 2017). Menurut OBE dan Templeman (2013) perlu disadari bahwa tujuan inovasi pendidikan adalah untuk merancang kerangka kerja kualifikasi keterampilan untuk seorang dewasa sehingga strategi penyampaian yang akan lebih efisien dan efektif dilakukan dengan:

1. Berlandaskan pada nilai-nilai kehidupan yang dianut peserta.

2. Pembelajaran memiliki kualitas tinggi dengan mengembangkan metode pembelajaran yang lebih baik secara terus menerus tanpa disertai pembiayaan tertentu yang dapat memberatkan peserta.

3. Profil reputasi yang kuat dan menambah kepercayaan peserta didik.

4. Dilengkapi topik terkini.

5. Dilengkapi strategi pemecahan masalah.

6. Sistem pembelajaran memberikan konektivitas antara pendidik dan peserta didik.

7. Pembelajaran lintas lembaga akan memberikan dampak positif bagi proses pengembangan peserta didik (non kompetitif).

8. Metodologi inovatif dengan konten-konten baru.

Di banyak bidang, diharapkan terwujud praktik pembelajaran yang inovatif. Dalam hal ini, dibutuhkan kerangka kerja dan pengetahuan yang kuat agar berhasil menjadi inovator/pengubah permainan yang efektif, OECD (2017) memberikan rekomendasi sebagai berikut: (1) prinsip pembelajaran untuk merancang lingkungan belajar, (2) kerangka kerja, (3) pembelajaran kepemimpinan dan berpikir evaluatif, serta (4) transformasi dan perubahan ekosistem pembelajaran.

Prinsip pembelajaran untuk merancang lingkungan belajar ini sebaiknya dibangun dengan menjadikan lingkungan sebagai pusat belajar yang membangun keterlibatan peserta didik secara kolaboratif menganalisis situasi sosial. Harapannya, hal ini akan selaras dengan emosi peserta didik yang mencerminkan adanya perbedaan individu. Penilaian dan umpan balik akan menciptakan keterhubungan horisontal yang prinsip keberhasilan lingkungan belajar ini telah ditentukan sebelumnya (OECD, 2017). 


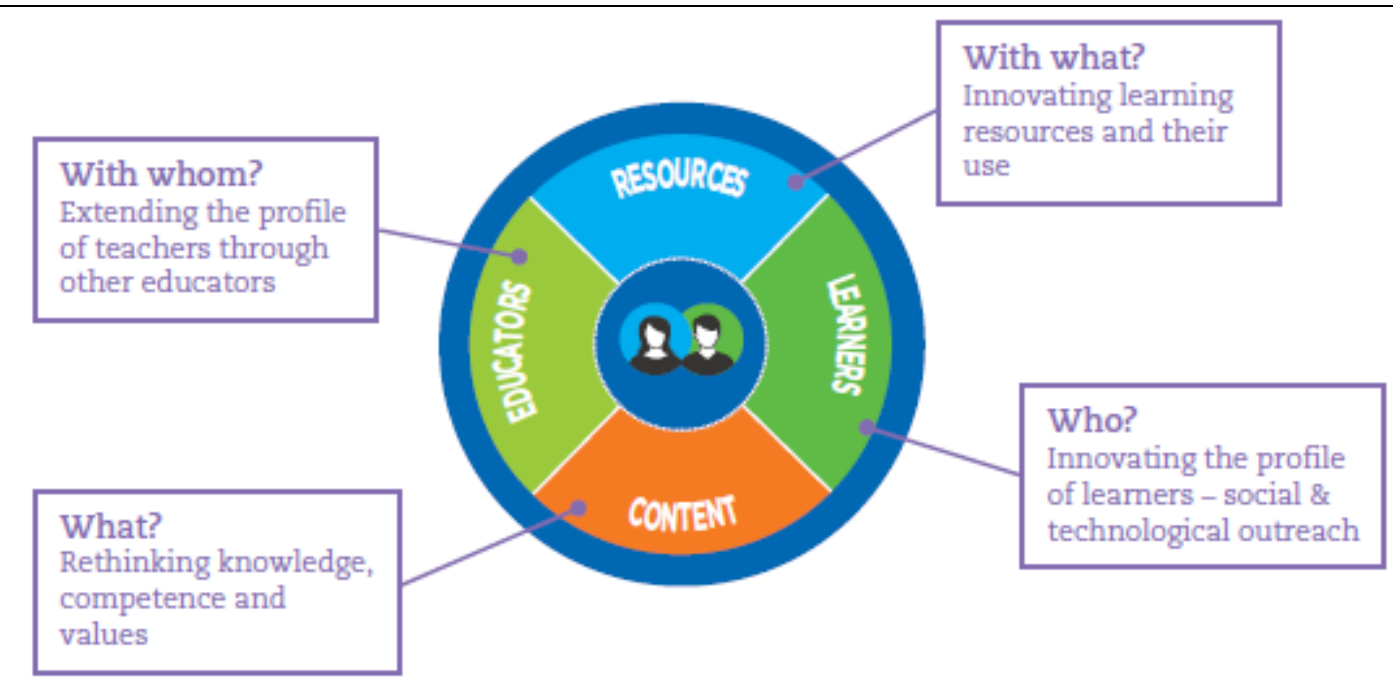

Source: Adapted from Figure 7.1 in OECD (2013), Innovative Learning Environments, http://dx.doi.org/10.1787/9789264203488-en.

Gambar 1.1. Elemen Inovasi dalam Inti Pedagogi Sumber:OECD (2017)

Gambar 1.1. mengenai elemen inovasi dalam inti pedagogi ini memberikan gambaran mengenai pembentukan kerangka kerja inovasi pendidikan. Hal ini dilakukan dengan mempertimbangkan aspek pertanyaan: siapa, apa, untuk siapa dan untuk apa. Kerangka kerja model pembelajaran juga sebaiknya dilakukan dengan menggabungkan prinsip pembelajaran dengan tiga arena dasar inovasi - inti pedagogis, pembelajaran kepemimpinan dan kemitraan (OECD, 2017).

Pembelajaran kepemimpinan dan berpikir evaluatif dilakukan demi mempertahankan kepemimpinan belajar sangat penting dalam implementasi dan keberlanjutan lingkungan belajar inovatif yang kuat. Kepemimpinan belajar perlu kreativitas dan keberanian serta bersifat sosial dan terhubung, dan semakin banyak pembelajaran itu lingkungan berinovasi, semakin banyak kepemimpinan pembelajaran akan datang dari berbagai mitra sering dipandang sebagai "eksternal" untuk pendidikan. Hal ini dpat dilakukan dengan seberapa jauh kepemimpinan difokuskan pada pembelajaran dan strateginya diinformasikan kemudian menerapkan serangkaian evaluatif proses: memperbaiki masalah (OECD, 2017). 


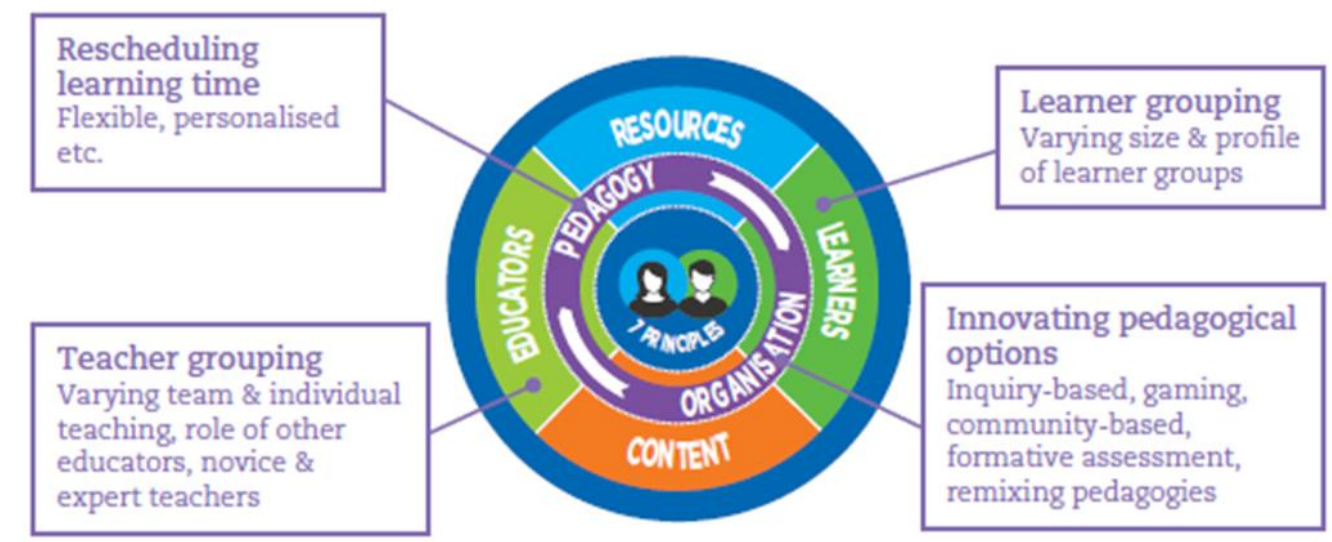

Source: Adapted from Figure 7.1 in OECD (2013), Innovative Learning Environments, http://dx.doi.org/10.1787/9789264203488-en.

Gambar 1.2. Dinamika Inovasi dalam Inti Pedagogi

Sumber: (OECD, 2017)

Gambar 1.2. mengenai dinamika inovasi dalam inti pedagogi ini mempertimbangkan transformasi dan perubahan ekosistem pembelajaran. Hal ini menggambarkan perlunya transformasi ekosistem pembelajaran. Menurut OECD (2017) Transformasi dan perubahan ekosistem pembelajaran ini dilakukan dengan cara:

1. Menggabungkan metode dan teori sebagai strategi baru yang diharapkan dapat mengarah pada inovasi yang diinginkan.

2. Membuat indikator yang digunakan untuk kemajuan sistem pendidikan menuju inovasi dan perubahan.

3. memberi para pemangku kepentingan sarana pemetaan sistem pembelajaran yang dinamis, menyatukan tingkat vertikal dan horisontal hubungan.

4. Pengajar harus terus mempelajari masa depan: keinginan masa depan yang berbeda dan cara bergerak menuju skenario yang disukai

\section{METODE PENELITIAN}

Penelitian ini merupakan sebuah studi kasus untuk menganalisis kualitas penyelenggaraan pendidikan bagi anggota Credit Union Kridha Rahardja (CUKR), menggali informasi terkait faktor-faktor yang menghambat penyelenggaraan pendidikan bagi anggota CUKR, dan memformulasikan desain kelembagaan yang mendukung peningkatan kualitas penyelenggaraan pendidikan anggota CUKR. Studi kasus merupakan sebuah studi tentang suatu sistem yang spesifik dan berfokus pada aspek-aspek yang relevan dengan pertanyaan 
penelitian (Stake, 1995). Studi kasus merupakan salah satu jenis metode penelitian kualitatif yang dipaparkan oleh Creswell (2006), dimana dalam penelitian kualitatif peneliti memegang peranan penting karena berada dekat dengan fenomena di lapangan dan dalam setting alamiah, memanfaatkan berbagai sumber data, menekankan pendekatan induktif dan intrepetatif, menganalisis kasus secara holistik dan fokus memperhatikan pemaknaan dari aktor-aktor di lapangan, dan tidak bersifat kaku terhadap rancangan penelitian awal.

Data yang akan digunakan dalam penelitian ini adalah data primer yang dikumpulkan dari hasil observasi dan wawancara mendalam dengan aktor yang terkait dengan isu di lapangan, serta data sekunder terkait berupa dokumen-dokumen pedoman penyelenggaraan pendidikan anggota yang diperoleh dari lembaga CUKR maupun asosiasi yang melingkupinya. Penelitian ini akan melakukan pengumpulan informasi dari sejumlah responden.

Pada tahap awal, pengumpulan data akan dilakukan di level lembaga CUKR, khususnya pimpinan pusat CUKR. Di tingkat pusat, responden yang akan diwawancarai adalah pengurus CUKR yang bertanggungjawab dalam pembuatan kebijakan terkait penyelenggaraan pendidikan anggota dan manajer CUKR selaku pimpinan pelaksana operasional. Di level pusat, akan dikumpulkan berbagai dokumentasi terkait pedoman, catatan, serta agenda penyelenggaraan pendidikan anggota di CUKR. Selanjutnya, pengambilan data dilakukan di level Tempat Pelayanan (TP) CUKR, yang terdiri dari TP Bawen (Semarang), TP Wedi (Klaten), dan TP Yogyakarta (Bantul). Di tingkat TP, wawancara akan dilakukan kepada staf TP serta aktivis TP yang bertanggungjawab dalam pelaksanaan pendidikan anggota. Di tingkat TP, juga akan dilakukan observasi terhadap kegiatan pendidikan yang diadakan oleh masing-masing TP pada periode pengambilan data penelitian. Selain itu, di dalam kegiatan pendidikan yang dilakukan setiap TP tersebut, akan dibagikan kuisioner survei bagi anggota peserta pendidikan untuk mendapatkan informasi terkait penilaian anggota terhadap aktivitas pendidikan yang mereka ikuti. Pada setiap kegiatan pendidikan bagi anggota TP tersebut, akan dilakukan wawancara dengan 2-3 responden untuk menggali informasi lebih mendalam terkait penyelenggaraan pendidikan yang mereka ikuti. Selain memanfaatkan aktivitas pendidikan yang diadakan oleh TP, pengumpulan data dari anggota juga dilakukan melalui kuisioner survei online maupun kuisioner yang akan disediakan di setiap TP yang dapat diisi oleh anggota saat bertransaksi di TP. 


\section{HASIL \& PEMBAHASAN}

\section{Informasi Umum Terkait Jenis Pendidikan CUKR}

Pendidikan yang diselenggarakan oleh CU Kridha Rahardja bagi anggota mencakup pendidikan pemahaman tingkat dasar (MENTAS), pendidikan melek keuangan (financial literacy) dan pelatihan kewirausahaan. MENTAS adalah pendidikan dasar yang wajib diikuti oleh 'sedulur' (sebutan bagi anggota) CU Kridha Rahardja (CUKR). ${ }^{2}$ Pendidikan pemahaman tingkat dasar dalam CUKR diadakan selama satu hari, dengan durasi 7-8 jam (waktu pelaksaaan dapat berbeda, ditentukan sesuai dengan kebijakan penyelenggaranya). Materi yang diberikan mencakup filosofi gerakan credit union, analisis sosial, pola pikir, usaha produktif, produk dan pinjaman di CUKR, serta anggaran dan belanja keluarga. Sementara itu, pendidikan melek keuangan CUKR bertujuan untuk membantu anggota memahami prinsip-prinsip dalam membuat keputusan keuangan dan produk keuangan yang berdampak pada kesejahteraan keuangan serta memperkenalkan seperangkat keterampilan dan pengetahuan terkait pengelolaan keuangan rumah tangga. Pendidikan tersebut membahas misi credit union yang sesungguhnya, produk dan pelayanan credit union yang disesuaikan dengan kebutuhan sedulur, mempelajari kaidah-kaidah keuangan, cara-cara menabung, pentingnya dana darurat, perencanaan kehidupan keuangan, dan penganggaran keluarga. Kemudian, pendidikan wirausaha adalah pendidikan yang dimaksudkan untuk memiliki jiwa dan kemampuan dalam berwirausaha serta meningkatkan pengetahuan dan ketrampilan anggota dalam mengembangkan usaha produktif. Materi-materi dalam pendidikan ini mencakup: (1) pengembangan jiwa kewirausahaan, (2) siklus usaha dasar, (3) pembukuan dasar, (4) pengelolaan resiko, (5) pemasaran, (6) keuangan, (7) sumber dan akses pendanaan, dan (8) pengembangan jaringan usaha, (9) rencana tindak lanjut, dan (10) teknis produksi.

\section{Penyelenggaraan pendidikan dan pelatihan CUKR berdasarkan perspektif pengelola CUKR}

CUKR belum memiliki kebijakan yang baku tentang pendidikan dan pelatihan. Sampai pertengahan tahun ini, penyelenggaraan pendidikan masih mengacu pada sistem lama yang

\footnotetext{
${ }^{2}$ Manual Operasional Pendidikan dan Pelatihan CU Kridha Rahardja. Istilah sedulur digunakan untuk menyebut anggota CU Kridha Rahardja.

Judul : Kajian Eksploratif Kualitas Penyelenggaraan Pendidikan Lembaga Keuangan Berbasis Pemberdayaan Masyarakat : Studi Kasus Credit Union Kridha Rahardja

(c) 2021 MSDJ : Management Sustainable Development Journal. Semua hak cipta dilindungi undang-undang
} 
dimiliki di CU Bererod Gratia. ${ }^{3}$ Sejak awal tahun 2019, CUKR sudah mencoba memformulasikan manual operasional pendidikan dan pelatihan yang baru dengan mengacu pada sistem pendidikan yang direkomendasikan oleh Badan Koordinasi Credit Union Kalimantan. Sistem inilah yang sementara ini diterapkan. Meskipun demikian, saat ini BKCU Kalimantan sedang mencoba menggali pembelajaran dari model pendidikan berbagai CU di Indonesia yang terafiliasi dengan BKCU Kalimantan untuk menentukan model payung yang dapat diterapkan oleh CU-CU. Ke depan, CUKR akan menggunakan model payung tersebut, tentunya setelah disesuaikan dengan konteks operasional CUKR.

Berkaitan dengan teknis penyelenggaraan pendidikan CUKR, hasil wawancara dengan sejumlah pengelola CUKR menunjukkan sejumlah fakta berikut. Pertama, materi (modul) pendidikan CUKR masih terlalu out-to-date dan dirasa terlalu berlebihan muatan jika dibandingkan dengan durasi penyelenggaraan kegiatan. Hal ini ditengarai membuat anggota menjadi kesulitan untuk memahami materi pendidikan yang diberikan secara baik. Oleh karena itu, para pengelola CUKR menyepakati perlu adanya pengkajian dan peramuan kembali materi pendidikan dan pelatihan yang mampu memberikan konten memadai namun juga menyenangkan bagi anggota. Kedua, sejumlah pengelola CUKR menyatakan perlunya ada dokumentasi yang lengkap dan evaluasi dalam setiap kegiatan pendidikan untuk menilai efektivitas penyelenggaraan pendidikan. Praktek tersebut belum dilakukan saat ini. Ketiga, pengelola CUKR mulai concern terhadap pentingnya memonitor dampak pedidikan bagi anggota terhadap setelah kegiatan pelatihan (kesadaran bahwa laporan yang berupa indikator kuantitatif seperti banyaknya latihan atau jumlah peserta tidak cukup untuk melihat kualitas dan dampak pendidikan bagi anggota). Hal ini mendorong pemikiran untuk memunculkan mekanisme dan alat monitoring dampak pendidikan bagi anggota. Kelima, terdapat fenomena ketidakmerataan kapasitas fasilitator pendidikan di masing-masing TP. Sehubungan dengan hal tersebut, pengelola akan merancang adanya penbelajaran bersama fasilitator CUKR serta mendorong pintu kolaborasi antar TP CUKR dalam memfasilitasi pendidikan CUKR.

\section{Penyelenggaraan pendidikan dan pelatihan CUKR berdasarkan perspektif anggota CUKR}

\section{Hasil Survei Penilaian Anggota Terhadap Penyelenggaraan Pendidikan CUKR}

\footnotetext{
${ }^{3}$ Pada awal berdirinya, CU Kridha Rahardja merupakan unit kerja CU Bererod Gratia yang berpusat di Jakarta. Pada awal tahun 2017, CU Kridha Rahardja beroperasi secara mandiri sebagai sebuah CU.

Judul : Kajian Eksploratif Kualitas Penyelenggaraan Pendidikan Lembaga Keuangan Berbasis Pemberdayaan Masyarakat : Studi Kasus Credit Union Kridha Rahardja 
Peneliti menggunakan 3 metode untuk menggali pandangan anggota terkait penyelenggaraan pendidikan CUKR, yaitu melalui observasi dan wawancara anggota peserta pendidikan dan kuisioner persepsional yang menanyakan respon dan tingkat pemahaman peserta terkait materi yang disampaikan saat pendidikan CUKR serta masukan terbuka terkait dengan penyelenggaraan pendidikan CUKR. Jawaban hasil survey valid yang didapatkan secara total adalah 108 buah. Dari sejumlah survei tersebut teridentifikasi bahwa sebagian besar peserta menyatakan sudah mampu menangkap materi pendidikan secara baik. Meskipun demikian, setelah mengikuti pendidikan anggota, peserta menyatakan belum cukup terdorong untuk menjadi aktivis (Abdi Sedulur/Komite/Pengawas/Pengurus) CUKR. Padahal, dalam Credit Union, hal ini penting untuk menjamin kaderisasi volunteer yang menjadi tonggak kekuatan Credit Union. Hal ini mengindikasikan bahwa pendidikan CUKR belum mampu mencetak kader militan dalam pengembangan CUKR. Sejumlah catatan yang perlu diperhatikan dari hasil survei adalah kurangnyanya pemahaman materi terkait analisis potensi dan permasalahan sosial anggota. Hal ini akan menjadi kelemahan terhadap pencapaian misi sosial CUKR, dimana CU perlu merespon persoalan sosial yang ada di tengah-tengah masyarakat dan mendayagunakan potensi yang ada di sekitarnya. Selain itu, peserta cenderung masih mengalami kesulitan dalam memilih jenis produk investasi keuangan yang tepat untuk mereka. Meskipun demikian, untuk pendidikan kewirausahaan. Secara keseluruhan pelatihan pendidikan kewirausahaan masih belum memperoleh rata-rata nilai yang baik. Dalam hal ini, CUKR perlu mendesain program pelatihan kewirausahaan yang mendorong peserta untuk mendirikan/mengembangkan usaha produktif, membuat perencanaan bisnis, menghitung resiko dan memperoleh ketrampilan baru untuk mengelola usaha produktif.

Sementara itu, berdasarkan hasil pernyataan terbuka tersebut dapat ditemukan sejumlah gejala terkait penyelenggaraan pendidikan CU Kridha Rahardja, yaitu:

1. Terkait dengan materi pendidikan. Materi pendidikan CU Kridha Rahardja sudah relatif baik dan berkontribusi besar dalam memberikan pemahaman terkait pengelolaan keuangan, dalam artian: (a) berpotensi mengubah pola pikir peserta ke arah yang lebih baik dan (b) berpotensi menjadi sarana pembelajaran bagi peserta dalam mengelola keuangan dan mencapai kemerdekaan finansial. Meskipun demikian, cakupan materi yang dibahas terlalu banyak dibandingkan dengan waktu yang tersedia sehingga membuat pembahasan menjadi kurang mendalam. Selain itu, peletakan 
urutan materi yang perlu dipertimbangkan kembali, baik ditinjau dari sisi urgensi materi dan alur pemaparan (dipastikan mengalir dan memudahkan peserta untuk mengikuti satu sesi ke sesi lain). Dalam kaitannya dengan urgensi materi, bagian esensial (menurut peserta: misalnya Anggaran Belanja Keluarga/ABK) sebaiknya tidak diletakan di bagian belakang.

2. Terkait dengan operasional penyelenggaraan. Peserta menilai persiapan dan fasilitas pendidikan sudah relatif baik. Meskipun demikian, terdapat kecenderungan adanya sejumlah fasilitator kurang mampu menyampaikan materi dan kurang menguasai materi pelatihan. Selain itu, pengorganisasian waktu dalam sejumlah kasus dapat dikatakan kurang baik, dalam artian: (a) Pelaksanaan molor, (b) Durasi pelaksanaan pendidikan yang terlalu panjang, (c) Jam pelaksanaan yang kadang kurang sesuai dengan sejumlah peserta (khususnya yang berkerja seminggu penuh). Selain itu, ada kecenderungan peserta mengalami kebosanan dan fokus perhatian berkurang ketika durasi kegiatan terlalu panjang.

\section{Hasil Analisis Penyelenggaraan Pendidikan CUKR Berbasis Observasi dan Wawancara}

Peneliti melakukan kajian kualitatif berbasis data hasil observasi penyelenggaraan pendidikan di Wedi (1 Diksar, 1 FL, dan 1 Pendidikan Kewirausahaan), di Yogyakarta (1 Diksar dan 1 FL) dan di Bawen (1 Diksar dan 1FL), serta wawancara dengan peserta pelatihan di Wedi (8 informan), di Yogya (6 informan) di Bawen (3 informan) yang dilaksanakan pada Juni-Agustus 2018.

Berdasarkan hasil analisis kualitatif berbasis observasi dan wawancara, dalam hal teknis penyelenggaraan pendidikan, potensi yang perlu menjadi perhatian masing-masing TP adalah kontribusi aktivis dalam penyelenggaraan pendidikan yang begitu bersemangat dalam mendukung kegiatan pendidikan CUKR. Sementara itu, kelemahannya adalah kurangnya persiapan dan koordinasi antara panitia penyelenggara pendidikan, termasuk fasilitator. Hal ini menimbulkan persoalan dalam hal pengorganisasian waktu dan efektivitas penyampaian materi.

Terkait dengan fasilitator dan materi, hal positif yang menonjol di CUKR adalah banyaknya tokoh berpendidikan dan berpengalaman yang mampu memfasilitasi pendidikan. Terdapat sejumlah fasilitator yang memiliki kelebihan masing-masing dan memiliki cara yang berbeda dalam menyampaikan materi. Jika dikolaborasikan, praktek-praktek tersebut akan 
menjadi kombinasi yang baik. Kelebihan lainnya adalah, dalam memfasilitasi pendidikan, fasilitator cukup banyak menggunakan contoh-contoh riil dan konteks lokal sehingga mudah dipahami peserta. Hal yang menjadi masalah adalah tidak semua fasilitator memiliki keahlian secara merata dalam mendesain penyampaiaan materi pendidikan. Selain itu, sejumlah fasilitator seringkali kurang mempersiapkan diri sebelum pelatihan sehingga, saat pelaksanaan pelatihan, mereka tampak tidak menguasai materi, tidak kreatif, dan tidak atraktif. Selain itu, seringkali banyak fasiitator yang kurang memiliki manajemen waktu dan pengolahan materi yang baik sehingga esensi materi kurang tersampaiakan atau waktu fasilitasi menjadi melebihi alokasi yang disediakan.

Terkait dengan peserta pendidikan, hal positif yang menjadi catatan penting dalam penyelenggaraan pendidikan adalah ada cukup banyak peserta yang sangat antusias dalam mengikuti kegiatan pendidikan. Mereka menyadari bahwa, melalui aktivitas pendidikan, mereka dapat menjadi ruang belajar bersama untuk memperoleh ilmu baru (terutama dalam mengelola keuangan) serta membangun jaringan kerja dan usaha. Latar belakang peserta yang berbda-beda juga menjadi salah satu hal yang dapat menggerakkan kegiatan karena mpeserta dapat saling berbagi pengealama yang berbeda. Sementara itu, hal yang menjadi persoalan terkait dengan peserta pendidikan adalah tingkat penyerapan materi yang berbeda-beda antar peserta pelatihan sehingga diperlukan materi dan metode pendidikan yang dapat mengakomodasi keaktifan peserta dengan tingat kemampuan yang berbeda-beda tersebut. Selain itu, ada kelompok anggota yang mengikuti pendidikan hanya karena formalitas saja dan kurang memiliki motivasi untuk belajar, sementara ada sejumlah peserta yang tidak mengikuti kegiatan sampai sesi akhir. Selain itu, tidak adanya monitoring dan analisis dampak pendidikan bagi anggota menimbulkan kesulitan bagi CUKR untuk menilai apakah pendidikannya sudah berjalan efektif dan berdampak bagi peserta.

\section{Rekomendasi penyelenggaraan pendidikan dan pelatihan CUKR}

Berangkat dari sejumlah analisis permasalahan di atas, peneliti merekomendasikan sejumlah usulan, yaitu:

1. Materi pendidikan yang ada ditilik, dikaji, ditata, dan dirumuskan kembali supaya lebih sederhana, aplikatif, mengalir, dan tepat sasaran-tujuan. Hal ini dilakukan dalam konteks penyediaan materi yang lebih akomodatif bagi seluruh anggota dengan variasi latar belakang pendidikan maupun pekerjaan; 
2. Pengorganisasian kegiatan semakin dioptimalkan melalui pembuatan standar pengorganisasian kegiatan pendidikan CUKR;

3. Pembuatan standar pengelolaan fasilitator yang ditopang dengan serangkaian kegiatan peningkatan kapasitas fasilitator (dalam hal ini, bukan berarti penyeragaman teknik fasilitasi pendidikan, namun justru integrasi berbagai sumber pengetahuan dan ketrampilan, termasuk yang dimiliki fasilitator);

4. Penyedian ruang belajar bersama yang berkelanjutan antara pengambil kebijakan diklat, penyusun materi diklat dan fasilitator. Bahkan, jika dimungkinkan, ruang belajar ini terbuka untuk anggota biasa (bukan pengelola ataupun aktivis) yang ingin bergabungdan terlibat dalam pengembangan pendidikan CUKR;

5. Perlunya monitoring dan evaluasi yang menganalisis dampak diklat (hal ini mensyaratkan perlunya ketersedian data diklat yang lebih lengkap, lebih jauh dari kuantitas pelaksanaan dan jumlah peserta yang terlibat dalam diklat);

6. Perlunya pendidikan nilai-nilai dasar yang lebih intensif bagi anggota CUKR, terutama dalam kaitannya dalam hal membuka pandangan anggota terkait peran kunci pendidikan dalam pengembangan CUKR, bukan sebatas formalitas transaksional;

7. Peneliti selanjutnya mendiseminasikan dan mendiskusikan hasil analisis dan rekomendasi penelitian tersebut kepada pengambil kebijakan pendidikan dan pelatihan CU Kridha Rahardja. Secara umum, pengelola CUKR tersebut menekankan pentingnya adanya standard kerja penyelenggaraan pendidikan. Khususnya bagi panitia penyelenggara dan fasilitator pendidikan CUKR.

\section{SIMPULAN \& SARAN}

Studi ini bertujuan untuk menganalisis kualitas penyelenggaraan pendidikan CU Kridha Rahardja, menganalisis persoalan yang terjadi di dalamnya, kemudian mengajukan rekomendasi perbaikan penyelenggaraan pendidikan CUKR. Pendidikan yang diselenggarakan oleh CU Kridha Rahardja bagi anggota mencakup pendidikan pemahaman tingkat dasar (MENTAS), pendidikan melek keuangan (financial literacy) dan pelatihan kewirausahaan. MENTAS adalah pendidikan dasar yang wajib diikuti oleh 'sedulur' (sebutan bagi anggota) CU Kridha Rahardja (CUKR). Berkaitan dengan teknis penyelenggaraan 
pendidikan CUKR, dari perspektif pengelola, terdapat sejumlah fakta persoalan penyelenggaran pendidikan CUKR berikut. Pertama, materi pendidikan CUKR masih terlalu out-to-date dan dirasa terlalu berlebihan muatan jika dibandingkan dengan durasi penyelenggaraan kegiatan. Kedua, tidak ada dokumentasi yang lengkap dan evaluasi dalam setiap kegiatan pendidikan untuk menilai efektivitas penyelenggaraan pendidikan. Ketiga, kurangnya monitoring dan evaluasi dampak pendidikan bagi anggota terhadap setelah kegiatan pelatihan. Keempat, terdapat fenomena ketidakmerataan kapasitas fasilitator pendidikan di masing-masing TP. Sementara itu dari perspektif peserta, persoalan materi dan keterbatasan kapasitas fasilitator juga mengemuka. Kelemahan pengorganisasian penyelenggaraan pendidikan serta sistem tata kerja fasilitator juga menjadi salah satu penghambat kelancaran kegiatan pendidikan.

Berangkat dari sejumlah kendala tersebut, peneliti merekomendasikan sejumlah usulan, yaitu: (1) pengkajian materi pendidikan sehingga lebih akomodatif bagi seluruh anggota dengan variasi latar belakang pendidikan maupun pekerjaan; (2) pengorganisasian kegiatan semakin dioptimalkan melalui pembuatan standar pengorganisasian kegiatan pendidikan CUKR; (3) pembuatan standar pengelolaan fasilitator yang ditopang dengan serangkaian kegiatan peningkatan kapasitas fasilitator; (4) penyedian ruang belajar bersama yang berkelanjutan antara pengambil kebijakan diklat, penyusun materi diklat, fasilitator, bahkan anggota biasa yang ingin bergabung dan terlibat dalam pengembangan pendidikan CUKR; (5) perlunya monitoring dan evaluasi yang menganalisis dampak diklat (hal ini mensyaratkan perlunya ketersedian data diklat yang lebih lengkap, lebih jauh dari kuantitas pelaksanaan dan jumlah peserta yang terlibat dalam diklat); (6) perlunya pendidikan nilainilai dasar yang lebih intensif bagi anggota CUKR, terutama dalam kaitannya dalam hal membuka pandangan anggota terkait peran kunci pendidikan dalam pengembangan CUKR, bukan sebatas formalitas transaksional. 


\section{REFERENSI}

Atkinson, A. B. (2014). After Piketty? The British Journal of Sociology, 65(4), 619-638. doi:10.1111/1468-4446.12105.

Barna Cristina \& Ancuţa Vamesu (2015). "Credit Unions in Romania: A strong social enterprise model to combat financial exclusion and over indebtedness", CIRIEC Working Paper, presented at 5th CIRIEC International Research Conference on Social Economy "The Social Economy in a Globalized World", ISCTE University Institute of Lisbon, (Portugal), July 15-18, 2015.

Byrne, Noreen, Olive McCarthy \& Michael Ward (2002) "No Study, No Credit Union: An Irish perspective on education and training in credit unions", A paper to the International Co-operative Alliance European and International Co-operatives Research Conference on Local Society and Global Culture 9-12th May, 2002, Thessaloniki, Greece.

Cerna, L. (2014), “Innovation, governance and reform in education”, CERI Conference background paper, 3-5 November 2014, www.oecd.org/edu/ceri/CERI\%20Conference\%20Background\%20Paper_formatted.p df.

Credit Union Kridha Rahardja (2019). Laporan Pertanggungjawaban Pengurus Credit Union Kridha Rahardja Tahun Buku 2018.

Creswell, J.W. (2006). Qualitative Inquiry and Research Design: Choosing Among Five Approaches. Sage Publication, London.

Inkopdit. (2017). Perkembangan GKKI tahun buku 2016. PICU, 36, 4-12.

Irnawan, T. (2010). Quo vadis, Gerakan Koperasi Kredit Indonesia? Inkopdit., Jakarta

Kalmi, P. (2012). Cooperative banking. In J. Toporowski \& J. Michell (Eds.), Handbook of critical issues in finance (pp. 56-65). Cheltenham: Edward Elgar Publishing Limited.

Kovacs, H. (2017). Learning and teaching in innovation: why it is important for education in 21 st century. Neveléstudomány, 5, 45-60.

Kusuma, Stephanus Eri (2017). "Institutionalizing Volunteerism In Credit Union: A Study Case Of CU Kridha Rahardja”, A conference paper presented in International Conference on Economics, Business, and Management Research 2017.

Kusumajati, T. O., \& Nopirin, M. (2012). Faktor ekonomi dan kelembagaan dalam keberlanjutan credit union di Indonesia. Universitas Gadjah Mada, Yogyakarta.

McKillop, Donal and John O.S. Wilson (2014). Recent Developments in the Credit Union Movement. Working Papers in Responsible Banking \& Finance No. 14-002 1st Quarter 2014. 
McKillop, D. G., \& Wilson, J. O. S. (2011). Credit unions: A theoretical and empirical overview. Financial Markets, Institutions \& Instruments, 20(3), 79-123.

doi:10.1111/j.1468-0416.2011.00166.Munawaroh, Munjati. (2005). Analisis Pengaruh Kualitas Jasa terhadap Kepuasan Industri Pendidikan di Yogyakarta. Jurnal Siasat Bisnis. Edisi Khusus JSB Marketing pp 119- 134.

Moghaddam, N., Best, B., Mendez, E. Dorsey., J. (2016). A New Look at Millenials and Credit Unions in America. Financial Partners Credit Union, GTE Financial, Patelco Credit Union, and The Center for Generational Kinetics, LLC.

OBE, C., C. Templeman, L. (2013). Adult Enterprise: Curriculum Innovation. Assosiation of Colleges.

OECD (2016). Innovating Education and Educating for Innovation: The Power of Digital Technologies and Skills. OECD Publishing, Paris.

OECD (2017). The OECD Handbook for Innovative Learning Environments. OECD, Publishing, Paris, http://dx.doi.org/9789264277274-en.

Syafrianti, Husna (2017). Pengaruh Pendidikan Dasar Anggota Terhadap Kewajiban Dan Tanggungjawab Anggota Pada CU Muare Pesisir Siantan. Program Studi Pendidikan Ekonomi Jurusan Pendidikan Ilmu-Ilmu Sosial Fakultas Keguruan Dan Ilmu Pendidikan Universitas Tanjungpura, Pontianak.

Stake, Robert E. (1995). The Art of Case Study Research. Sage Publication, California, United States.

Sumarwan, Antonius, and Taruk, Fredy Rante (2016). "Credit Unions as Actors of SocialEconomic Empowerment for the Poor and Their Impact on Members: A Case Study of the Sauan Sibarrung Credit Union, Toraja)", International Indonesia Forum, 2016 Working Paper Series.

Volkova, Tatjana \& Brigita Baltaca (2013). "Credit Unions: Social Enterprise at Work", Science Journal of Business Management, Volume 2013, Article ID sjbm-284,9 Pages, doi: 10.7237/sjbm/284. 